Saeed Moshiri, Farideh Atabi, Mohammad Hassan Panjehshahi,

Stefan Lechtenböhmer

\title{
Long run energy demand in Iran: a scenario analysis
}

Originally published as:

Saeed Moshiri, Farideh Atabi, Mohammad Hassan Panjehshahi, Stefan Lechtenböhmer (2012):

Long run energy demand in Iran: a scenario analysis

In: International Journal of Energy Sector Management, Vol. 6 Issue 1, pp. 120-144

DOI 10.1108/17506221211216571 
Saeed Moshiri a, ${ }^{*}$, Farideh Atabi ${ }^{\mathrm{b}}$, Mohammad Hassan

Panjehshahi ${ }^{c}$, Stefan Lechtenböhmer ${ }^{d}$

\section{Long run energy demand in Iran: a scenario analysis}

a Department of Economics, STM College, University of Saskatchewan, Saskatoon, Canada

${ }^{\mathrm{b}}$ Department of Environmental Engineering, Graduate School of Environment and Energy, Science and Research Branch, Islamic Azad University, Tehran, Iran

${ }^{c}$ Department of Chemical Engineering, University of Tehran, Tehran, Iran

${ }^{\mathrm{d}}$ Wuppertal Institute for Climate, Environment, Energy, Wuppertal, Germany

* Corresponding author: Saeed Moshiri, Department of Economics, STM College, University of Saskatchewan, 1437 College Drive, Saskatoon, Saskatchewan, S7N 0W6, Canada

E-mail: moshiri.s@usask.ca

Phone: +1-306- 9668913

Fax: +1-306- 9668904 


\title{
Long Run Energy Demand in Iran: a Scenario Analysis
}

\begin{abstract}
Iran as an energy-rich country faces many challenges in the optimal utilization of its vast resources. High rates of population and economic growth, a generous subsidies program, and poor resource management have contributed to rapidly growing energy consumption and high energy intensity over the past decades. The continuing trend of rising energy consumption will bring about new challenges as it will shrink oil export revenues restraining economic activities. This calls for a study to explore alternative scenarios for the utilization of energy resources in Iran. In this study, we model demand for different types of energy in Iran using a technoeconomic or end-use approach and develop two business-as-usual and efficiency scenarios for the period 2005-2030.

The results indicate that Iran has a huge potential for energy savings. Specifically, under the efficiency scenario, Iran will be able to reduce its energy consumption 40 percent by 2030.The energy intensity can also be reduced by about 60 percent to a level lower than the world average today. Furthermore, the energy savings under the efficiency scenario will generate significant additional revenues and will lead to a 45 percent reduction in $\mathrm{CO}_{2}$ equivalent emissions by 2030 as compared to the BAU trend.
\end{abstract}

Key words: Scenario analysis, end-use, energy efficiency, Iran

JEL Classification: O13, O53, Q2, Q4 


\section{Introduction}

Possessing 11 percent of global oil reserves and 15.3 percent of global natural gas reserves (second only to Russia), Iran is one of the major players in the world energy market and in the global economy. However, a rapid increase in its own demand for energy has raised concerns about the country's ability to continue to export oil and to improve its economic and environmental conditions. Iran's crude oil export has already declined from an average 2,561 thousand barrels per day in the 1990s to 2,364 thousand barrels per day during the 2000s (EIA, 2011). Iran has become increasingly dependent on gasoline imports as gasoline consumption has been rising due to the rapidly increasing number of passenger cars and the low price of gasoline. The use of natural gas and electricity has also been swiftly rising on average at the rate of 16.4 and 5.9 percent per year over the past 30 years and more than doubling in recent years (Table 1). Furthermore, sanctions for investment and production in the energy sector by the U.S., and recently the EU and the $\mathrm{UN}$, have made it harder to meet the rising trend in energy consumption in Iran. As Table 1 shows, the total primary energy consumption has increased by 5.8 percent while the total primary energy production has increased by only 4.3 percent over the past 30 years (EIA, 2011).

If the current trend in energy consumption continues, Iran will have to cut its exports of crude oil and natural gas to meet domestic demand. A decline in oil exports would have a dramatic impact on the economy, which is heavily dependent on oil revenues. More than half of government revenues and 80 percent of total export revenues come from oil exports, and many economic activities, particularly in the manufacturing industry sector, rely on imports of intermediate goods which are financed by oil export revenues (Central Bank of Iran, 2009). The rising energy consumption has also caused deterioration of environment and health conditions, particularly in large cities such as Tehran ${ }^{1}$.

The increasing energy consumption in Iran is partly due to the country's fast growing economy (Medlock and Soligo, 2001), but the large energy subsidies and poor management have aggravated the consumption trend. The share of subsidies in the government budget has reached about 12 percent (Farzanegan and Markwardt, 2009) and the per capita energy consumption has been rising by 5 percent, on average, over the past 40 years. However, the energy intensity in Iran is one of the highest in the world, representing a high level of inefficiency in the use of energy (EIU, 2006). 
Table 1 - Energy Production and Consumption Trends in Iran (1980 - 2008)

\begin{tabular}{lcccc}
\hline & 1980 & 2008 & $\begin{array}{c}\text { Growth } \\
\text { (annual, } \\
\%)\end{array}$ & Ratio** \\
\hline Total Oil Supply (Tbd*) & 1683 & 4179.62 & 4.7 & 1.1 \\
Dry Natural Gas Production (Bcf) & 250 & 4107.13 & 16.0 & 2.4 \\
Total Primary Energy Production (Quadrillion Btu) & 3.94 & 13.35 & 4.3 & 1.3 \\
Total Petroleum Consumption (Tbd) & 590 & 1741.9 & 4 & 1.3 \\
Dry Natural Gas Consumption (Bcf) & 232 & 4212.73 & 16.4 & 2.4 \\
Total Primary Energy Consumption (Quadrillion Btu) & 1.58 & 8.121 & 5.8 & 1.7 \\
Total Electricity Net Consumption (Billion kWh) & 19.68 & 161.46 & 5.9 & 1.9 \\
\hline
\end{tabular}

*Tbd: Thousand barrels per day, Bcf: Billion cubic feet

**Ratio is the ratio of average figures of the corresponding item in the 2000 s to that in the 1990 s.

Source: US Energy Information Administration, International Energy Statistics, 2011

Although scenario studies on the future demand for energy are abundant, they have mostly focused on OECD or major developing oil-importing countries such as China and India (van Benthem and Romani, 2009, Adams and Shachmurove, 2007, Rana, 2003, Pesaran et al., 1998). The research on energy demand in energy-rich countries such as Iran is limited and most of the studies cover only a specific sector, an energy type, or short-run forecasting (Jiang and Hu, 2005, Davoudpour and Ahadi, 2006, Ahmadian, et al., 2007, Sadeghi and Hosseini, 2008). The fact that scarcity has not been deemed a critical economic or political issue in energy-rich countries may explain the limited research in this area. Distorted prices and lack of data along with tight government control of the energy sector may also have been a contributing factor in discouraging energy demand studies in those countries.

In the present study, we model energy demand in Iran by different energy carriers and in different sectors of the economy using a techno-economic or end-use approach. In some cases, where time series data are available, the regression method is also employed. Given the highly distorted energy market in Iran, where government fully controls supply and prices, using conventional econometric methods is not always appropriate as they produce misleading results that cannot be used for future projections. For instance, the elasticities for different energy types are often not significant as prices have been kept very low for a long period. Using those elasticities to forecast future demand would generate biased results, as the low prices are not sustainable and the elasticities will likely change (Fettini, 2003). The techno-economic approach, in such a case, can produce more reliable results in long run scenario analysis as it relies on fundamental factors, which are not subject to short-term fluctuations. It also does not solely draw on historical data but takes into account the likely technological, structural and policy changes in the future. The shortcomings of this approach are that it requires a high number of numerical inputs for which finding reliable data might not be easy (Larsen and Nesbakken, 2004) and that it 
does not fully account for changes in energy prices and substitution dynamics considered in econometric models. The results of the end-use approach may also depend on ad-hoc considerations about the parameters of the model (See Bhattacharyya and Timilsina, 2010, for a comparative study of energy modeling approaches). Notwithstanding the shortcomings, making sound assumptions and more realistic scenarios may provide a better understanding of the challenges and potential solutions to the steeply rising energy demand in Iran.

This study is a comprehensive study that models Iranian energy demand using the enduse approach and data for all economic sectors at different aggregation levels and a combination of methods to illuminate the future of energy demand under alternative scenarios. The results of the study have great policy implications as they indicate a huge potential for energy conservation and therefore additional revenues and emission reduction under the efficiency scenario compared with the base scenario. We will first present a brief review of modeling energy demand in section 2 followed by an overview of Iran's economic and energy sector indicators in section 3 . We then use the model to estimate the demand under a business-as-usual (BAU) scenario as our base scenario in section 4 and apply efficiency measures to examine potential energy savings under the efficiency scenario in section 5. In section 6, we discuss the economic and environmental implications of the study and in section 7 we present concluding remarks.

\section{Modeling Energy Demand}

There are two general approaches to model final energy demand: Top-down and bottom-up. The top-down or econometric method uses historical data at the macro level to estimate consumption trend and the effects of socio-economic variables on the demand for energy. These models rely on the economic theory on demand for inputs (derived demand) and employ variables such as prices and income as major determinants of the demand for energy. The bottom-up, also called technoeconomic or engineering approach, however, uses energy billing data and detailed survey information on household, appliances, and capital characteristics to determine the end-use energy consumption by each type of appliance or capital and to simulate the total energy consumption for the sector, region, or economy.

The techno-economic approach has some advantages over the conventional top-down or econometric models which are commonly used in energy demand analysis. First, the econometric models use historical data to capture the trend and macroeconomic and socioeconomic effects, but they often require data that reflect market equilibrium, which may not be available in a developing country, such as Iran, due to government intervention in the market and distorted 
prices. The techno-economic models get around this problem by using non-price observations based on energy surveys, technical studies, and energy audits. Second, the techno-economic models generate more accurate predictions than econometric models in the long run as they are more flexible in taking into account all information and allowing for future policy changes in forecasting. Third, relying on continuous historical data, econometric models do not fully capture the technological effects and structural changes, both of which are critical in the analysis of energy consumption. Therefore, those models often do not adequately address the effects of new technologies or change in regimes on energy consumption. Disadvantages of the bottom-up models are the requirement for detailed input information and many assumptions on household or firm behavior. They also do not use economic variables and are computationally intensive.

Top-down and bottom-up approaches have been used extensively in the energy demand modeling literature. For instance, Bentzen and Engsted (2001) use a simple econometric model to estimate energy consumption in Denmark. Hass and Schipper (1998) develop an econometric model to estimate energy elasticies in the US, Japan, Sweden, Germany, and the UK for different time periods. Filippini and Hunt (2011) apply the stochastic frontier analysis to estimate energy demand and energy efficiency in the OECD countries for the period 1978-2006. Crompton and $\mathrm{Wu}$ (2205) use the Bayesian Vector Autoregressive model to forecast China's demand for energy. Examples of applications of the bottom-up approach are Kohler et al. (1997) for the German building sector, Huang and Broderick (2000) for the American building stock, Murakami et al. (2009) for the building sector in Japan, Palmer et al. (2006) for housing energy demand in UK, Farahbakhsh et al. (1998) for the Canadian housing stock, Lechtenböhmer and Schüring (2011) for the EU building stock, and Griffith et al. (2007) for commercial buildings in US. Koopmans and te Velde (2001) combine these approaches by using a top-down model and employing bottom-up information to estimate demand for energy in Netherland.

In general, the selection of one or the other approach depends on the objective of the study. If the aim is to study the long-run trend, assuming that there would not be a discontinuity, or to obtain elasticities to conduct short run macro policy analysis, the top-down approach may be the better option for modeling energy demand. However, as Swan and Ugursal (2009) indicate, if the objective is to evaluate the effect of new technology or to examine an efficiency scenario with significantly altered policies in this field, the advantages of the bottom-up approach would outweigh its disadvantages, and, therefore, it would be a better choice ${ }^{2}$. Furthermore, as Bhattacharyya and Timilsina (2010) and Urban et al. (2007) argue, the econometric approach is based on the idea of representative consumers or producers and might generate biased results 
when applied to developing countries where consumption behavior varies widely by income group and by location. The bottom-up approach is more appropriate for modeling energy in developing countries because it takes into account developing country features such as ruralurban differences, traditional and modern energies, transition to modern economy, and nonmonetary transactions.

The demand for energy is a derived demand as energy is used to generate services like heat or light for households or businesses. Therefore, it depends on the equipment (capital) that uses energy. The demand for energy of type $\mathrm{j}$ in sector $\mathrm{h}$ with $\mathrm{M}$ capitals at time $\mathrm{t}$ can be modeled as follows.

$E_{\text {hjt }}=\sum_{i=1}^{M} \varphi_{i t} e_{i j t} K_{i t}, h=1, \ldots, H, j=1,2, \ldots, J$

Where $\mathrm{E}_{\mathrm{hjt}}$ is the demand for energy of type $\mathrm{j}$ in sector $\mathrm{h}$ at time $\mathrm{t}, \mathrm{K}_{\mathrm{it}}$ is an $\mathrm{i}^{\text {th }}$ energy-using capital or a consumer durable goods, $e_{i j t}$ is the type $j$ energy coefficient for capital $i$, and $\varphi_{i t}$ is the utilization rate of capital i. Although price and income, the main components of the energy demand models in econometric models, are not present here, they affect $\mathrm{E}$ indirectly through their impacts on the parameters e and $\varphi$ (Pesaran et al., 1998). Estimating $\mathrm{E}$ requires detailed information on $\mathrm{K}$ as well as energy consumption behavior parameters e and $\varphi$. This data is usually available through household or industry energy surveys, expert surveys, technical studies, and energy audits. In some cases, where the desired disaggregated data is not available, we rely on econometric analysis to obtain historical trend, but adjust the results for the likely structural and major policy shifts when we use them for long run forecasting. In our study we analyze four sectors $(\mathrm{H}=4$; household, industry, transport, and others: commercial, public, and agriculture $)$, and six energy carriers $(\mathrm{J}=6$; fuel oil, gas oil, kerosene, gasoline, electricity, and natural gas).

\section{An Overview of the Economy and the Energy Sector}

Iran is a developing mid-income and resource-rich country with an oil-centered economy. Oil export revenues account for 80 percent of total export earnings, nearly 50 percent of the government revenues, and 23 percent of GDP (Central Bank of Iran, 2008). Although the recent high oil prices have improved the external financial conditions quite considerably, high inflation coupled with high unemployment and volatile growth rates, are still major challenges for policy makers. Table 2 summarizes the major economic and energy statistics in Iran. 
Table 2 - Economic and Energy Indices in Iran

\begin{tabular}{|c|c|c|c|c|}
\hline Economy & & Rank & & \\
\hline $\begin{array}{l}\text { GDP (PPP) } \\
\text { GDP per capita } \\
\text { GDP growth } \\
\text { Foreign debt }\end{array}$ & $\begin{array}{c}\$ 599.2 \mathrm{~b} . \\
\$ 8700 \\
5 \% \\
\$ 23 \mathrm{~b} .\end{array}$ & $\begin{array}{l}22^{\text {nd }} \\
98^{\text {th }}\end{array}$ & $\begin{array}{l}\text { Population } \\
\text { Population growth } \\
\text { Unemployment rate } \\
\text { Inflation rate }\end{array}$ & $\begin{array}{c}70.5 \\
1.3 \% \\
12 \% \\
13-15 \%\end{array}$ \\
\hline \multicolumn{5}{|l|}{ Energy } \\
\hline $\begin{array}{l}\text { Oil reserves } \\
\text { Oil exports } \\
\text { Natural gas reserves } \\
\text { Natural gas production } \\
\text { Electricity production } \\
\end{array}$ & $\begin{array}{l}132.5 \mathrm{bbo} \\
2.5 \mathrm{bbl} / \mathrm{day} \\
26.62 \mathrm{tcm} \\
83.54 \mathrm{bcm} \\
186 \mathrm{TWh} \\
\end{array}$ & $\begin{array}{c}3^{\text {rd } *} \\
4^{\text {th }} * * \\
2^{\text {nd }} \\
7^{\text {th }} \\
21^{\text {st }}\end{array}$ & $\begin{array}{l}\text { Oil production } \\
\text { Natural gas exports } \\
\text { Natural gas imports } \\
\text { Electricity generation capacity } \\
\text { Total primary energy production }\end{array}$ & $\begin{array}{l}4 \mathrm{bbl} / \mathrm{day} \\
3.56 \mathrm{bcm} \\
5.2 \mathrm{bcm} \\
37.3 \mathrm{GW} \\
2121 \mathrm{Mboe}\end{array}$ \\
\hline
\end{tabular}

The total final energy consumption in 2005 (our base year) was 783 million boe. Household's share of total final energy consumption was about 37 percent, industry 21 percent, transport 28 percent, and others (agriculture, public, commercial, and non-energy use)14 percent. Electricity consumption in 2005 was 144 TWh, out of which household's share was 32 percent, industry's 33 percent, and other's 34 percent (Iran Energy Balance, 2007). The energy use per capita has been increasing on average by 5 percent annually for the past 40 years. The energy intensity index has also been increasing on average by 3.4 percent since 1967, indicating a decreasing trend in the efficiency of energy use. The energy intensity in Iran is as high as the Middle East average, but twice as high as the world average. The energy factor, defined as the ratio of the final energy use growth to the GDP growth, is also very high (1.27) compared to the world average (0.41), reflecting an unproductive use of energy (Iran Energy Balance, 2007). The stage of development, poor management, and the generous energy subsidies, estimated up to 12 percent of $\mathrm{GDP}^{3}$, are the main driving forces behind the rising consumption and inefficiency.

\section{Business as Usual (BAU) Scenario}

The BAU scenario describes a likely energy demand path if no far-reaching changes in consumption patterns are made. Therefore, it assumes that the economy and the energy sector will basically follow the past trends. It also takes into account new developments in the economy based on patterns of world economic growth as well as policies outlined in the national FiveYear-Development-Plan (FYDP) and the 20-year vision approved by the Iranian authorities. 
GDP and population growth are two major variables driving energy demand. Using past trends and recent developments and policies, we project the future values of those variables. Economic growth and population growth have been relatively high but volatile for the past 30 years; the average economic growth rates have been $-1.3,6.3$, and 8.2 percent for the $1980 \mathrm{~s}$, 1990s and 2000s, respectively. The negative growth rates in the 1980s were due to the Iran-Iraq war, and higher growth rates afterward were mainly due to higher oil prices and post-war reconstruction activities. The economic growth rates are expected to slow down and stabilize as the economy reaches a higher level of development in the next 25 years. Therefore, we assume GDP will grow by 5.5, 3.4, and 3 percent in the next three decades. The population has been growing on average by 2.3 percent over the past 30 years, but the rates have changed considerably within this period. The population growth rates have been $3.4,1.7$, and 1.5 percent for the 1980s, 1990s, and 2000s. The unprecedented population growth rates in the 1980s were mainly due to the removal of the family plan programs and government support for larger family sizes after the 1979 revolution. However, the change in the family plan policy in the 1990s led the population growth to slow down. We assume the population will continue to grow on its long run trend by 1.3 percent over the next 20 years, but will slow down to 0.9 percent as the economy develops in the 2020s.

In the following section, we present the results for the energy demand by households for fuel and electricity using aggregate and survey data. We will then present the model's results for the manufacturing industry using survey data and for the transport sector using both survey and aggregate data. The agriculture, commercial, and public sectors will be presented as other sectors. In deriving the BAU scenario results, the model is calibrated in every sector to the base year $(2005)^{4}$. A diagram showing the organization of the work is provided in the appendix.

\subsection{Households}

Households account for about 37 percent of the total final energy consumption. They use about 20 percent of the total oil products, 63 percent of natural gas, and 32 percent of total electricity consumption. The household energy consumption pattern has changed markedly since 1990 because of government's policy of substituting natural gas for oil products. Household consumption of oil products has increased on average by about half a percent annually, but the consumption of natural gas and electricity have increased by 19 percent and 6 percent per year for the past 15 years, respectively (Iran Energy Balance, 2007). We study household demand for energy in two sections; Fuel and electricity. In the fuel section, we model the demand for oil 
products and natural gas using aggregate data. In the electricity section, we model the demand for electricity using detailed household survey data.

\section{Fuel}

Natural gas is now a major energy carrier in the residential sector. In 2005, Iranian households used about 63 Mboe oil products such as gas oil and LPG, and about 197 Mboe natural gas. According to the National Iranian Gas Company (NIGC), 7.5 million households had access to natural gas in 2004, which is projected to grow on average by about 3 percent annually until 2025. This means that every year about 33000 new households will join the natural gas grid. The estimated regression results show that population and GDP are significant factors in explaining the changes in demand for oil and gas by household, with the former having a stronger effect. Using the estimated values for future demand and future shares of each energy type based on the existing and the future government policies, we break down the results into demand for kerosene, gas oil, LPG, and natural gas. One of the key factors in estimating the future shares of energy carriers in household demand for oil and natural gas is the government policy to increase the share of natural gas in the household fuel basket from 79 percent to 95 percent. Accordingly, shares of kerosene, gas oil, and LPG are assumed to decrease from 16, 2.6, and 2.7 percent in 2005 to 2,2 , and 1 percent in 2030 , respectively.

The use of oil and natural gas by households is broken down into space heating, cooking, and water heating and their shares are assumed to remain the same during the study period. Table 3 shows the BAU scenario for household consumption of oil products and natural gas in different types of use. The total demand for oil products and natural gas by household is projected to grow by 3.35 percent per year on average, increasing from 259 Mboe in 2005 to 592 Mboe in 2030.

Table 3 - BAU Scenario Results for Household Demand for Oil Products and Natural Gas

\begin{tabular}{llll}
\multicolumn{4}{c}{$(2005-2030)$} \\
Energy Carrier & $\begin{array}{l}2005 \\
(\text { Mboe })\end{array}$ & $\begin{array}{l}2030 \\
(\text { Mboe })\end{array}$ & $\begin{array}{l}\text { Growth /yr } \\
(\%)\end{array}$ \\
\hline Kerosene & 47 & 13 & -4.97 \\
Gasoil & 8 & 13 & 2.11 \\
LPG & 8 & 7 & -0.68 \\
Natural Gas & 197 & 559 & 4.25 \\
Total & 260 & 592 & 3.35 \\
\end{tabular}

Source: Energy balance (2007) and authors' estimations. 


\section{Electricity}

Household demand for electricity is estimated using an end-use approach. This approach uses technical data that allows for analyzing various scenarios regarding the changes in technology and consumption patterns. The demand for electricity (E) by a household depends on the electrical appliances and their penetration rates as follows:

$$
\begin{aligned}
& E_{t}=\sum_{j=1}^{M}\left(\varphi_{j t} e l_{j t}\right), \\
& e l_{j t}=e_{j t} K_{j t}
\end{aligned}
$$

Where $\varphi$ is the penetration rate and $\mathrm{el}_{\mathrm{jt}}$ is the amount of electricity used by each appliance measured by the number of appliances (K) multiplied by their energy coefficients (e). M is the total number of appliances in a household. The total demand for electricity (TE) can then be estimated using the information on population and family structure as follows.

$$
T E_{t}=\left[N \times(1+r)^{t} / n\right] \times(C / H) \times\left(E_{t}\right)
$$

where $\mathrm{N}$ is the population in the initial year, $\mathrm{r}$ the population growth rate, $\mathrm{n}$ the size of the household, $\mathrm{C}$ the number of customers, and $\mathrm{H}$ the number of households. Although the very detailed micro data on household consumption of energy is not available in Iran, there is some survey data in Tehran by Tehran Regional Electricity Company (TREC) along with other published reports by TAVANIR (the public utility corporation), which can be used to analyze and estimate the electricity demand for household at a disaggregated level.

The major appliances used by Iranian households are reported in Table 4. Most modern appliances are used in the urban households, but as the economy develops the penetration rates of new appliances and electronic devices will increase. The major changes are assumed to occur in the penetration of lamp, freezer, microwave, air conditioner, and computer. The government policy to encourage the use of low consumption lamps (CFL) and the gradual realization of the benefits of using those lamps by households will lead to a higher penetration rate of new lamps. As income rises, the use of some appliances such as freezer, microwave, tea/coffee maker, washing machine, and particularly, air conditioner and computer will also increase. There is no data on appliances for the rural areas, but using some general information about living conditions of the households in rural areas, the penetration rates of appliances for these households are estimated. For instance, the penetration rates for appliances such as freezer, microwave, and washing machine are assumed zero and for appliances such as TV and refrigerator a fraction of 
the urban penetration rates. The total penetration rates are obtained by applying the appropriate weights, which are the shares of urban and rural households using electricity.

Table 4 - Penetration Rates and Electricity Consumption of Electric Appliances per Household,

\begin{tabular}{|c|c|c|c|c|c|c|}
\hline \multirow{2}{*}{ Appliance } & \multicolumn{2}{|c|}{ Urban } & \multicolumn{2}{|c|}{ Rural } & \multicolumn{2}{|c|}{$\begin{array}{l}\text { Electricity } \\
\text { Consumption }(\mathrm{kWh} / \mathrm{y})\end{array}$} \\
\hline & 2005 & 2030 & 2005 & 2030 & 2005 & 2030 \\
\hline Lamp<100 W & 3.98 & 3.5 & 3 & 4 & 391 & 329 \\
\hline Lamp $100 \mathrm{~W}$ & 2.83 & 2.83 & 2 & 2.83 & 485 & 561 \\
\hline Fluorescent Lamp 5 & 2.61 & 2 & 2 & 1.5 & 315 & 132 \\
\hline Low consumption Lamp & 0.22 & 1.50 & 0.22 & 1.50 & 1 & 53 \\
\hline Refrigerator & 1.02 & 1.05 & 1 & 1.05 & 590 & 525 \\
\hline Freezer & 0.44 & 0.7 & 0 & 0.3 & 186 & 308 \\
\hline Mixer & 0.47 & 0.47 & 0 & 0.2 & 9 & 8 \\
\hline Soft cooker & 0.29 & 0.4 & 0 & 0.1 & 31 & 48 \\
\hline Microwave & 0.17 & 0.5 & 0 & 0.2 & 16 & 67 \\
\hline Tea/coffee Maker & 0.04 & 0.5 & 0 & 0.2 & 1 & 26 \\
\hline Vacuum Cleaner & 0.76 & 0.9 & 0 & 0.3 & 60 & 83 \\
\hline Washing Machine & 0.65 & 0.9 & 0 & 0.5 & 69 & 113 \\
\hline Iron & 0.88 & 1 & 0 & 0.5 & 157 & 252 \\
\hline Cooler(water system $)^{6}$ & 0.83 & 0.8 & 0.70 & 0.7 & 111 & 83 \\
\hline Air Conditioner & 0.10 & 0.3 & 0 & 0.1 & 170 & 387 \\
\hline TV & 1.01 & 1.2 & 0.7 & 1 & 233 & 424 \\
\hline Computer & 0.25 & 1 & 0 & 0.4 & 13 & 95 \\
\hline
\end{tabular}

Source: Tehran Regional Electricity Company (TREC), 1996, 2001, and authors' estimation

Table 5 shows the results of the BAU scenario for household electricity demand for the period 2005-2030. The number of customers, consumption per household, and total consumption of electricity by households will grow more rapidly in rural areas than urban areas. The share of electricity consumption of urban households in total households' electricity consumption will reduce by 0.5 percentage point from 85 percent to 84.5 percent. The number of residential customers (households) will grow by 1.2 percent, consumption per household by 1 percent, and the total electricity use by households by 2 percent on average for the period 2005-2030. 
Table 5 - Residential Demand for Electricity, BAU Scenario (2005-2030)

\begin{tabular}{llll}
\hline & $\mathbf{2 0 0 5}$ & $\mathbf{2 0 3 0}$ & Growth (\%) \\
\cline { 2 - 4 } & & & \\
Urban & 12.14 & 16.3 & 1.19 \\
Number of Customers (million) & 3,319 & 3,742 & 0.48 \\
Consumption per household per year (kWh) & 39,790 & 65,890 & 2.04 \\
Total Consumption (GWh) & & & \\
Rural & & & \\
Number of Customers (million) & 4.4 & 5.96 & 1.22 \\
Consumption per household per year (kWh) & 1,538 & 2,565 & 2.07 \\
Total Consumption (GWh) & 6,836 & 12,119 & 2.32 \\
& & & \\
Total & 16.54 & 22.26 & 1.19 \\
Number of Customers (million) & 46,626 & 78,009 & 2.08 \\
Total Consumption (GWh) & & & \\
\hline Sout TAVANR rion
\end{tabular}

Source: TAVANIR reports and authors' calculations.

\subsection{Industry}

Industry accounts for about 42 percent of the Iranian GDP, and uses about 21 percent of total final energy (Central Bank of Iran, 2007, Iran Energy Balance, 2007). Natural gas is the dominant source of energy in industry, which accounts for nearly half of the total energy used in this sector. The share of natural gas in the total energy use by industry has been increasing because of government's aggressive policy of substituting natural gas for oil products. We model energy demand in industry using the survey data on manufacturing industries with more than 10 workers available through the Statistics Center of Iran. We use information at the two digit ISIC (International Standard of Industry Codes) level in which the manufacturing industries are classified into nine main industry groups. The list of industries is presented in Table 6. Machinery and Equipment manufacturing industry is the largest industrial group in Iran accounting for about 36 percent of the total manufacturing industries value-added. Chemical and Basic Metals each produce 13 percent, and Refinery produces 9 percent of the total value-added by industrial groups. The shares of Food and Beverages, Non-Metallic Minerals, and Textiles and Leather in total valued-added are 9,8 , and 6 percent, respectively.

Chemical industry has the highest energy use (27 percent) among the manufacturing industry groups, followed by Basic Metals (18 percent), Non-Metallic Minerals (16 percent), Refinery (11 percent), and Food and Beverages (10 percent). About 48 percent of energy used by the manufacturing industry is natural gas, 26 percent fuel oil, 17 percent electricity, 7 percent gas oil, 1.7 percent liquefied petroleum gas (LPG), 0.6 percent gasoline, and 0.3 percent kerosene. $^{7}$ 
We use the following equation to estimate the energy demand by manufacturing industries in the BAU scenario:

$$
E=\sum_{i} e_{i} \cdot V A_{i}
$$

where e is the energy intensity and VA the value-added. The current value added for each group is converted to the constant value-added using the corresponding price deflators and the future value-added for each manufacturing industry projected using the past growth rates taking into account the objectives outlined in the Ministry of Industry plans, the fourth national FYDP (20042009) and the 20-year vision. Most manufacturing industries are expected to grow on average at a

Table 6- Manufacturing Industries Value Added and Energy Use (2005-2030)

\begin{tabular}{lllllll}
\hline & $\begin{array}{l}\text { Value Added } \\
\text { Constant } \\
1997 \mathrm{~b} .\end{array}$ & $\begin{array}{l}\text { Share } \\
\text { Rials }\end{array}$ & $\begin{array}{l}\text { Energy } \\
\text { Use } \\
(2005) \\
\text { Mboe }\end{array}$ & $\begin{array}{l}\text { Share } \\
\%\end{array}$ & $\begin{array}{l}\text { Energy } \\
\text { Use } \\
(2030) \\
\text { Mboe }\end{array}$ & $\begin{array}{l}\text { Growth } \\
\text { (annual, } \\
\%)\end{array}$ \\
\hline Food and Beverages & 7,083 & 9 & 17 & 10 & 44 & 4 \\
Textile and Leather & 4,426 & 6 & 5 & 3 & 8 & 2 \\
Wood and Wood Products & 279 & 0.4 & 1 & 0.5 & 1 & 1 \\
Paper, Pulp and Printing & 1,440 & 2 & 4 & 3 & 10 & 4 \\
Chemical and Petrochemical & 10,598 & 13 & 44 & 27 & 106 & 4 \\
Refinery & 7,184 & 9 & 19 & 11 & 45 & 4 \\
Non-metallic Minerals & 6,610 & 8 & 26 & 16 & 59 & 3 \\
Basic Metals & 10,008 & 13 & 29 & 18 & 72 & 4 \\
Machinery and Equipment & 28,854 & 36 & 7 & 4 & 16 & 4 \\
Other industrial & 3,119 & 4 & 13 & 8 & 19 & 1 \\
Total & 79,601 & 100 & 165 & 100 & 380 & 3.4 \\
\hline
\end{tabular}

Source: The Large Manufacturing Industries Survey, Statistics Center of Iran, and authors' calculations.

rate of 8 or 9 percent at the beginning of the period and at a rate of 4 to 6 percent per year at the end of the study period. The future energy demand for manufacturing industry groups is estimated using the energy intensity and the estimated value added for each group and each energy type for the period 2005-2030. In deriving the BAU scenario, the recent negative trend in energy intensity and the gasification policy of the manufacturing industry, particularly in Food and Beverages, Wood and Wood Products, Textile and Leather, and Paper, Pulp and Printing industries, are taken into account. The results shown in Table 6 indicate that the total energy demand by the manufacturing industries will grow on average by 3.4 percent per year increasing from 164 Mboe in 2005 to 380 Mboe in 2030.

Table 7 shows the demand for energy in manufacturing industries by energy types. It was projected using a sector by sector distribution of energy carriers. Further it was assumed that due 
to government policy and structural changes, natural gas will have the highest growth rates followed by LPG, gasoline, and gas oil.

Table 7 - Manufacturing Industries Demand for Energy by Energy Types, BAU scenario - Mboe

\begin{tabular}{|c|c|c|c|}
\hline & 2005 & 2030 & Growth (\%) \\
\hline Kerosene & 0.54 & 0.96 & 2.3 \\
\hline Gasoil & 12 & 26 & 3.3 \\
\hline Natural Gas* & 77 & 200 & 3.9 \\
\hline LPG & 3 & 7 & 3.5 \\
\hline Gasoline & 1 & 2 & 3.5 \\
\hline Fuel Oil & 42 & 88 & 3.0 \\
\hline Electricity & 28 & 54 & 2.6 \\
\hline Total & 165 & 380 & 3.4 \\
\hline
\end{tabular}

\subsection{Transport}

In 2005, the transport sector used about 28 percent of the total final energy consumption, 54.7 percent of the total oil product consumption, 0.16 percent of natural gas, and 0.07 percent of electricity (Iran Energy Balance, 2007). That year, about 450 billion passenger kilometers were travelled by car (54\%), bus (41\%), train (2\%), and airplane (2\%). Also about 208 billion toneskilometer freight has been transported by trucks $(92 \%)$ and train $(8 \%)$. The main energy carriers used in the sector are gas oil, gasoline, kerosene, and jet fuel. Natural gas (LPG and CNG) has also been added to the energy basket of the sector, but its share is negligible. We use the following equation to estimate the demand for energy in the sector:

$E_{t}=\sum_{i} V_{i t} \cdot T_{i t} \cdot e_{i t}$

where $V_{i t}$ is the total number of vehicles of type $i$ at time $t, T_{i t}$ is the travel distance per vehicle $i$ per year, and $\mathrm{e}_{\mathrm{it}}$ is the specific energy consumption by vehicle type $\mathrm{i}$ at time $\mathrm{t}$. Note that this is similar to equation 1 where $\mathrm{C}_{\mathrm{it}}=\mathrm{K}_{\mathrm{it}}$, and $\mathrm{T}_{\mathrm{it}}=\varphi$. The vehicle types are passenger car, bus, and trucks. The number of vehicles is estimated using a regression equation with population and GDP as two main explanatory variables. The energy carriers are gasoline, gas oil, and CNG for vehicles. The demand for energy by train, air, and sea transport are estimated separately.

Basic information about road transport is summarized in Table 8 . The number of passenger cars is about 6 million in 2005 and will grow with per capita income. The regression results indicate that GDP and population are the two main drivers in the demand for cars ${ }^{8}$. Specifically, in the past 30 years (1976-2005), for every 1 billion rials (constant 1997 values) on 
average 2,000 new vehicles, and for every 1 million addition to population, 17,000 new vehicles are added to the transport system. Because of a low gasoline price, a boom in car manufacturing industries, and higher income, the number of cars has been growing rapidly in recent years, but it is expected to stabilize when the market is saturated. According to the estimation results, the number of cars will grow on average at the rate of 4.5 percent per year to 18.26 million cars in 2030. The total travel distance per car per year is $24,000 \mathrm{~km}$ on average, which is expected to reduce to $22,000 \mathrm{~km}$ as the use of public transport will grow rapidly. The average gasoline consumption by passenger cars is 14 liters per 100 kilometers, which is very high compared to international standards. We assume that improvements in technology and higher income will allow for the use of more efficient cars in the future, reducing the gasoline consumption to 7.5 liters per $100 \mathrm{~km}$ in 2030. Total gasoline consumption by passenger cars is 20 billion liters in 2005 , but will grow on average by 1.62 percent per year to about 30 billion liters in 2030 . The same approach is applied to buses and public transport. Total gas oil consumption by buses is 5.3 billion liters in 2005 , but will decrease on average by 0.87 percent per year to 4.3 billion liters in 2030. The reason for a decline in gas oil demand by bus is that the specific energy consumption will decrease at a faster rate than the total travel distance will increase.

Table 8. Passenger Transport Indicators - BAU Scenario (2005 - 2030)

Private 2005 2030

Number of cars (million)

Average total travel distance by a passenger car per year ( $\mathrm{km} / \mathrm{year}$ ) Total travel distance by passenger cars per year (million km/year) Average load per car (person)

Total gasoline consumption by passenger cars (m. liter)

Public

Number of buses

Average travel distance by bus per year ( $\mathrm{km} /$ year)

Total travel distance by bus (millionkm/year)

Total travel distance by passengers - bus (million person $\mathrm{km} / \mathrm{year}$ )

Average gas oil consumption by bus (liter/100 km)

Total gas oil consumption by bus (million liter)

Total travel distance by train (million person $\mathrm{km}$ )

Total gasoil consumption by train (million liter)

Total travel distance by air (million person $\mathrm{km}$ )

Total fuel consumption by airplane (million liter)

Source: Ministry of Road and Transportation reports and authors' calculations.
6

24,000

144,000

1.7

244,800

14

20,160

18.26

22,000

401,632

1.5

602,449

7.5

30,122

$233,000 \quad 358,000$

$45,000 \quad 41,250$

$10,496 \quad 17,219$

$182,682 \quad 382,497$

$51 \quad 25$

$5,353 \quad 4,305$

$11,149 \quad 29,708$

$95 \quad 253$

$10,985 \quad 29,284$

1,630

3,166 
Table 9 shows total consumption of different energy types used by the transport sector. Gasoline and CNG will be the major energy types used in the sector and the final energy demand, which is 217 Mboe in 2005, will grow on average by 2 percent per year to 354 Mboe in 2030.

Table 9 - Final Energy Demand by Transport Sector- BAU Scenario (2005-2030) - Mboe

\begin{tabular}{llll}
\hline & 2005 & 2030 & $\begin{array}{c}\text { Growth/yr } \\
(\%)\end{array}$ \\
\hline Gasoline & 108 & 161 & 1.62 \\
Gasoil (buses and trucks) & 88 & 156 & 2.31 \\
CNG & 6 & 8 & 1.16 \\
Gasoil (train) & 2 & 5 & 3.73 \\
Jet fuel & 10 & 20 & 2.81 \\
Ship fuel & 2.48 & 3.82 & 1.75 \\
Total & 216.5 & 353.8 & 1.98 \\
\hline Source: Authors' calcluations & & &
\end{tabular}

\subsection{Total Energy Demand in the BAU Scenario}

Total demand for final energy will increase on average by 2.8 percent per year from 783 Mboe in 2005 to 1549 Mboe in 2030 in the BAU scenario. Manufacturing industries will have the highest growth in demand for energy with an average growth of 3.4 percent per year followed by the residential and transport sectors with 3.2 and 2 percent annual growth, respectively. Demand for energy in the other sectors (commercial, agricultural, public) will grow on average 1.7 percent. Table 10 and Figure 1 show the BAU Scenario results for energy demand in different sectors for the period 2005-2030.

Table 10 - Total Final Energy Demand in Iran by Sectors, BAU Scenario (2005-2030) - Mboe

\begin{tabular}{llllll}
\hline & 2005 & $\begin{array}{l}\text { Share } \\
(\%)\end{array}$ & 2030 & $\begin{array}{l}\text { Share } \\
(\%)\end{array}$ & $\begin{array}{l}\text { Growth } \\
(\% / \text { year })\end{array}$ \\
\hline Households & 289 & 37 & 638 & 41 & 3.2 \\
Manufacturing Industries & 164 & 21 & 379 & 24 & 3.4 \\
Transport & 218 & 28 & 356 & 23 & 2 \\
Others & 114 & 14 & 175 & 11 & 1.7 \\
Total & 783 & 100 & 1549 & 100 & 2.8 \\
\hline
\end{tabular}

Source: Iran Energy Balance (2007) and author's calculations.

[Figure 1 here]

The structure of energy demand will change because of policies and technological changes over the study period. Specifically, the shares of households and manufacturing industries of total energy consumption will increase from 37 and 21 percent to 41 and 24 percent 
in 2030, respectively. Increasing shares of household and manufacturing industries in total demand for energy are mainly due to the increase in population, urbanization and economic activities in those sectors. The share of transport will decrease from 28 percent to 23 percent due to saturation in the sector coupled with the use of higher efficient vehicles and government policies in promoting public transportation. Table 11 and Figure 2 show the changes in total energy demand by all sectors and the shares for the period 2005-2030.

In the BAU scenario, natural gas demand will have the highest growth rate with about 4 percent growth per year on average, increasing from 309 Mboe in 2005 to 822 Mboe in 2030. The demand for oil products (fuel oil, gas oil, and ga soline) will grow on average between 1 and 2.2 percent. Demand for kerosene, however, will decrease on average by 4.7 percent per year in this period.

Table 11- Total Final Energy Demand by Type of Energy, BAU Scenario (2005-2030), Mboe

\begin{tabular}{lccccc}
\hline & 2005 & Share $(\%)$ & 2030 & Share $(\%)$ & Growth $(\%)$ \\
\hline Gasoline & 110 & 14 & 164 & 11 & 1.61 \\
Kerosene & 50 & 6.4 & 15 & 1 & -4.70 \\
Gas oil & 147 & 19 & 245 & 16 & 2.06 \\
Fuel Oil & 54 & 7 & 93 & 6 & 2.20 \\
Natural Gas & 309 & 40 & 822 & 53 & 3.99 \\
LPG & 11 & 1.4 & 13 & 0.8 & 0.67 \\
CNG & 6 & 0.8 & 8 & 0.5 & 1.16 \\
Jet Fuel & 10 & 1.3 & 20 & 1.3 & 2.81 \\
Electricity & 85 & 11 & 167 & 11 & 2.75 \\
Total & 783 & 100 & 1,549 & 100 & 2.8 \\
\hline
\end{tabular}

Source: Authors' calculations

[Figure 2 here]

\section{Energy Efficiency Scenario}

Improving the end-use energy efficiency is one of the most important ways to reduce energy consumption in different sectors of the economy (Aydinalp et al, 2001). In the efficiency scenario, we focus on energy intensity, which changes with advancement in technology and a change in the structure of the economy. All other things being constant, more efficient technology will decrease the energy intensity. A change in the structure of the economy in favour of less energy intensive production will also reduce the energy intensity. Our primary concern in this scenario will be a change in energy intensity due to a change in technology. For instance, in 
the household sector, we assume that CFLs and other appliances that are more efficient than current stocks will substitute the traditional inefficient devices. Likewise, in the transport sector, we assume that cars with more efficient engines will drive away the cars with low efficient engines. Furthermore, we assume that an energy price reform will induce a more efficient use of energy in different sectors ${ }^{9}$. Improving energy efficiency after price and non-price policy changes requires changes in capital over time (Koopmans and Velde, 2001). We assume existing capital will be retrofitted in the medium-term and new capital, production process and techniques will be replacing existing ones in the long run.

\subsection{Households}

For the heating sector, the following assumptions are made:

- For existing buildings, a renovation rate of 2 percent will be applied. This means that during a period of 50 years, all buildings will be renovated to a better standard. The energy saving per building will be 50 percent on average, a value that has already been shown to be feasible in several case studies in Iran. The technical potential to make a building more efficient is about 90 percent.

- For new buildings in 2010 and later, a standard that is about 80 percent better than the average consumption of today's buildings will be applied.

- By the year 2030 about 10 percent of houses will be demolished and replaced by new and better buildings and the size of the living area per person will increase by 10 percent.

- For the supply of hot water, a higher efficiency through better boilers and better insulation of storage tank and taps will be applied.

Overall, total energy demand for fuel by households in the efficiency scenario is estimated to be 52 percent less than that in the BAU scenario in 2030. For electricity used by households, it is assumed that, by the year 2020, compact fluorescent bulbs will substitute 50 percent of the incandescent lamps that households are using today, and in the year 2030, households will substitute 80 percent of the incandescent lamps. Therefore, electrical use by lights in the residential sector in 2030 will be about 40 percent less in the efficiency scenario compared to the BAU scenario. The average electrical consumption of a refrigerator in 2020 is assumed to be 20 percent higher than that of an average refrigerator bought in central Europe today. For the year 2030, the average consumption could be 20 percent higher than that of the most efficient refrigerators, which are sold in Europe today. The same relationship is assumed for freezers and combined appliances (refrigerator and freezer in one appliance). The overall electricity consumption by refrigerators and freezers in the residential sector in 2030 will be 67 percent less 
in the efficiency scenario compared to the BAU scenario. Using irons equipped with thermostatregulation would lead to a 50 percent reduction in electrical use for ironing. Electricity consumption of this appliance would still be five times higher than the consumption for ironing in Germany. It is also assumed that there will not be a significant change in the water cooler system, but there will be an efficiency improvement in the new air conditioning systems. Although the need for cooling may decrease, the amount of equipment and comfort demands and as a result, cooling loads will increase. Overall, the electricity consumption for the cooling systems in the residential sector will be reduced by 30 percent in 2030 under the efficiency scenario compared to BAU. It is assumed that there will not be a significant change in electricity consumption by computers, but because of changes from CRT-monitor to LCD-monitor TV, electricity consumption of TV-devices will go down 25 percent by 2030. For other appliances no changes in efficiency are assumed.

The average electrical consumption by households in the efficiency scenario is estimated to be 42 percent lower than that in the BAU scenario and thus, more than 25 percent below the current level despite higher penetration rates and higher comfort levels per household. To achieve the efficiency scenario outcomes in the household sector, a set of price and non-price policies are required. Although price reform in which electricity prices would reflect the actual production costs is essential to encourage efficient use of energy, it is not sufficient and should be accompanied by non-price policies. For instance, production of appliances and buildings should be regulated so the minimum energy efficiency standards are met. Rather than subsidising energy consumption, government can also provide incentives to encourage producers and consumers to produce and use more efficient appliances and buildings. Public awareness about the negative consequences of the current trend of energy consumption and education on efficient devices (e.g. by energy labelling) and on how to use energy efficiently will also be important in achieving the energy efficiency targets in different sectors, particularly households.

\subsection{Industry}

The manufacturing industry in Iran has seen immense growth rates of almost 15 percent per year over the last 15 years, which has led to significant increases in energy consumption. In spite of decreases of energy intensity of about 7 percent per year between 1990 and 2005, the energy intensity of many industrial installations is still significantly above (about 36 percent) world average. This is mainly due to low energy prices, lack of capital for investment in new and/or more efficient machinery, and poor management in industrial plants, which are mostly owned and operated by the state. Energy savings in industry can be achieved by reforming energy prices as 
well as implementing non-price policies such as efficient motor systems, improved monitoring and process control, process optimization and integration (pinch analysis), and recycling. An efficient motor system can reduce electricity consumption of electric motor systems, which account for 65 percent of the electricity consumption use by industry. Improved monitoring and process control, which includes monitoring and targeting, computer integrated manufacturing and process (temperature, airflow, moisture, oxygen, etc.) control, can account for 2 to 18 percent of energy savings in industry. Process optimization and integration (pinch analysis) saves energy by matching components of the system in terms of size, function, and capability. It is especially important when there are multiple heating and cooling demands in a production plant. The potential saving by process optimization and integration is 10 to 25 percent. Finally, recycling, especially in the aluminium and steel production, can reduce energy use in industry. Producing aluminium by recycled scrap will use only 5 to 10 percent of the energy used to produce aluminium, because it involves re-melting the metal instead of the electrochemical reduction process (Graus and Harmelink, 2006, ECOFYS, 2007).

To estimate energy demand under the efficiency scenario, we use the results of manufacturing auditing reports by the Iran Energy Efficiency Organization (SABA), a subsidiary of the TAVANIR, Ministry of Energy, and the Iran Fuel Conservation Organization (IFCO), a subsidiary of National Iranian Oil Company, between 2000 and 2007. These results indicate that improved monitoring and process control are the most important sources of energy savings in the metallic and particularly aluminium plants. They also demonstrate that using best practice technology would lead to high energy savings of more than 40 percent on average in sugar, glass, steel, brick, stucco, lime, iron and steel plants. Using existing auditing results, we set up the following efficiency scenarios for energy demand in industry.

- The real monetary growth and physical production will be decoupled by a rate of 1 percent per year in the future (as in the BAU scenario), as is typical in more advanced economies. It is also assumed that existing plants will increase their production levels through higher capacity utilization and expansions by about 1 percent per year. The residual production will come from completely new producing sites. By 2030, the number of plants will almost double and new installations will account for about 50 percent of physical production.

- For the technical standard of refurbished and new power plants, the current best available technology (BAT) will be utilized. This standard will further improve in the future by about 1 percent per year. For sectors not covered by the analyses of SABA, an average 
savings factor of 50 percent by using BAT versus currently installed technology has been assumed based on detailed study results from Graus and Harmelink (2006).

- It is further assumed that existing plants will be almost completely (83 percent) renewed by 2030. This would enable most existing plants to produce with BAT by 2030 .

In the efficiency scenario, a further decline in energy intensity by more than half, or an annual rate of 3.1 percent, will be achieved by 2030. Although this decrease in energy intensity in industry is a continuation of the past trend, its realization requires strong policies to promote efficiency. Overall, the total energy consumption by industry in the efficiency scenario will be 41 percent less than that in BAU scenario in 2030.

\subsection{Transport}

Fuel efficiency in the transport sector can be achieved in two ways; change in the number of cars and travel distance, and change in technology. The basic assumption in the transport sector is that the price of gasoline and gas oil will eventually increase to the border prices. In this case, the number of private vehicles will be lower and the average yearly travel distance will be shorter compared to the BAU scenario. Furthermore, the share of public transport will increase, mainly because of the higher cost of private cars. We assume that the number of private cars will grow from 6 million cars in 2005 to about 18 million cars in 2030 (as in BAU-scenario). The average travel distance per private car will decline from 24,000 km/year to 17,600 km/year (a 20 percent decrease compared to the BAU scenario). This is still about 60 percent more than the average travel distance per car in developed countries such as Germany today.

Passenger cars can be more fuel efficient if they have better engines, reduced weights, friction, and drag. Hybrid cars, which combine a conventional engine with an electric engine, are now consuming about 4.3 litre $/ 100 \mathrm{~km}$. This rate can further decline when new light materials and new propulsion technologies are used. The average specific energy consumption for private cars in Iran under the BAU scenario will decrease from 14 litre/100 km to 7.5 litre/100km by 2030. We assume that in 2020, the average consumption of private cars in Iran will be the same as in Germany in the year 2006, which was 7.8 litres/100km. For the year 2030, we further assume that private cars will consume gasoline on average the same amount of a fairly efficient middle-class car today, that is 6 litres $/ 100 \mathrm{~km}$. The efficiency of buses and trains will rise by 20 percent and the efficiency of aviation will rise by 45 percent through newer and bigger planes. Overall, the total energy used in the transport sector in the efficiency scenario will be 35 percent lower than that in the BAU scenario. 
To achieve the targets above, the gasoline subsidies should be removed so the price of gasoline reaches the border price levels. Furthermore, more investment in public transport and train system is necessary to provide alternative modes of transportation, particularly in large cities. Efficiency regulation for car manufacturing plants to reduce their energy intakes and produce more efficient cars is also critical. Car manufacturers in Iran have long been under government protection policies such as low interest loans, high tariffs on imported cars, and low gasoline prices. Although the policies have helped the industry grow markedly, they have led to a compromise in the standard and quality of the products. Changing travel behaviour, providing public services using internet and telephone, improvement in road conditions, and consumer awareness on the energy efficient cars and their impacts on environment will also help reduce gasoline consumption.

\subsection{Total Energy Savings under the Efficiency Scenario}

The total final demand for energy under the efficiency scenario will grow on average by 0.5 percent per year from 783 Mboe in 2005 to 894 Mboe in 2030. This means that the efficiency scenario will lead to more than 42 percent energy savings compared to the BAU scenario by the year 2030. The lion's share of savings in this scenario will be in the household sector with more than 50 percent lower fuel consumption compared with BAU. Savings in industry, transport, and others will be between 30 and 40 percent. Demand for all energy careers will decline in the efficiency scenario relative to the BAU scenario. The most significant decline will be in the natural gas and electricity consumption, which will decrease by about 50 percent. Gasoline consumption will also decrease considerably by about 42 percent. Consumption of gas oil, fuel oil and LPG will decrease by about one third. The results are summarized in Table 12.

Table 12 - Total Final Energy Demand in Alternative Scenarios, (2005-2030), Mboe

\begin{tabular}{lcccc}
\hline & \multicolumn{2}{c}{$\begin{array}{c}\text { Final Energy Demand } \\
\text { (Mboe) }\end{array}$} & Growth (\%) & Saving (\%)* \\
\cline { 2 - 3 } Scenario & 2005 & 2030 & & \\
\hline BAU & 783 & 1,549 & 2.8 & - \\
Efficiency & 783 & 894 & 0.5 & 42 \\
\hline
\end{tabular}

* Saving is relative difference between the energy consumption in the BAU scenario versus the efficiency scenario by 2030.

Total demand for electricity will almost double in BAU scenario in 2030 reaching from 85 Mboe in 2005 to $167 \mathrm{GWh}$ in 2030, that is a 2.7 percent average annual growth. It will, however, increase to $108 \mathrm{Mboe}$, an average annual growth of 1 percent, in the efficiency scenario. The most significant potential for reduction in electricity consumption is in the manufacturing 
industry followed by the other sectors (agriculture, commercial, and public). Figure 3 shows the trends of the demand for energy under the two scenarios.

[Figure 3 here]

Lack of similar studies for Iran does not allow us to compare our results with others, but we note that our results are more conservative than those reported by Davoudpour and Ahadi (2006) for the household demand for energy. In our study, demand for final energy by households will grow on average by 3.4 percent under BAU and -0.6 percent under the efficiency scenarios for the period 2005-2030, but the results of the top-down econometric method used by Davoudpour and Ahadi show an annual growth rate of 7.5 percent under the BAU and 4.94 percent under efficiency scenarios for the period 2000-2011. A more comprehensive projection is the World Energy Outlook by IEA whose overall results are comparable with our BAU results. According to the IEA's projection, total primary energy demand will grow on average by 2.6 percent for the period 2003-2030, while our results show a 2.8 percent annual growth for the period 2005-2030. Compared with our study, IEA overestimates demand growth for oil (1.9 percent vs 1.4 percent), but underestimates (2.9 percent vs 3.6 percent) demand growth for natural gas.

\section{Economic and Ecological Impacts of Scenarios}

The impacts of the examined scenarios should be of great importance for policy makers facing the socio-economic challenges due to the increasing energy consumption. For instance, in the BAU scenario, the export capacity of crude oil and natural gas will continually decrease because of increasing domestic consumption. With the current trend, it is probable that Iran might not be able to export any oil in the mid-2030s. In the efficiency scenario, however, the Iranian export capacities of oil and gas would decrease more slowly, sustaining the country's export capacity at least until the middle of the century. To calculate energy related GHG emissions, we assume that oil products emit $468 \mathrm{~kg} \mathrm{CO}$ per barrel and natural gas about $310 \mathrm{~kg} \mathrm{CO}$ per barrel of oil equivalent. Electricity produces $1,128 \mathrm{~kg} \mathrm{CO}$ per barrel of oil equivalent which decreases by 2030 to $852 \mathrm{~kg}$ due to higher shares of natural gas and higher efficiency of power plants as well as some non fossil generation. For reasons of simplicity, $\mathrm{CO}_{2}$-equivalent emissions resulting from conduction losses of gas and burning off during oil production as well as methane and other GHG emissions are not taken into account here.. 
The $\mathrm{CO}_{2}$-equivalent emissions will increase proportionately to the oil and gas consumption and thus will almost double by 2030 under the BAU scenario. This also applies to other pollutants, such as nitrogen oxides, sulphur dioxide, dust and heavy metals, with considerable economic follow-up costs and risks to the public, especially in the high population density areas. In the efficiency scenario, $\mathrm{CO}_{2}$-equivalent emissions as well as contamination with other pollutants would decrease considerably. The results show that $\mathrm{CO}_{2}$-equivalent emissions under the efficiency scenario will be reduced by 39 percent in 2020 and 45 percent in 2030 vs. BAU. $^{10}$

\section{Conclusion}

Energy use in Iran has been increasing rapidly over the past decades and will continue to grow in the future. Our study shows that Iran's demand for energy will increase annually by 2.8 percent, on average, which is 1.4 percentage points more than the average growth rate of the global demand for energy over the next 25 years (WEO, 2008). Part of the excessive growth in energy consumption in Iran can be explained by the stage of development of the country, but heavy subsidies on energy consumption and poor management of energy resources may also be driving forces behind the fast growing use of energy. The fast growing domestic energy consumption will hinder long run economic growth as it will curb the country's ability to export oil and natural gas, which are the main sources of revenue for economic activities in Iran. It will also exacerbate the environmental problems, particularly in highly populated and industrialized areas. Our scenario study results show significant potentials for energy savings in Iran. Specifically, the total final energy demand under the efficiency scenario will be 42 percent less than that in BAU scenario and the energy intensity will decline by about 60 percent by 2030 , to a level lower than world average today, but still higher than Germany's intensity target for 2020.

The realization of the energy efficiency scenarios in Iran will lead to significant revenues as the oil saved domestically can be exported to the international markets. The efficiency scenario will also lead to a 45 percent reduction in energy related $\mathrm{CO}_{2}$ emissions by 2030 as compared to the BAU trends. This means that emissions can be maintained at current absolute levels in spite of economic and population growth. To achieve the measures under the efficiency scenario, the current policy of providing subsidies to energy consumption, particularly in the residential and transport sectors needs to be revised. Furthermore, non-price policies, such as education and public awareness, energy consumption regulation for producers of appliances and vehicles as well as consumers will be needed to slow down the increasing consumption trend, while maintaining 
an increase of energy services and reducing economic and environmental burdens of energy consumption.

This study is a comprehensive study, which uses survey and aggregate data for different sectors of the economy and different types of energy, to project future energy demand in Iran under the BAU and efficiency scenarios. However, we must outline the following caveats. First, just as in cases of developing countries, the quality of the data may not be reliable, particularly in certain types of data such as household survey data. Unfortunately, such survey data are not available on a regular basis, which would allow errors to be identified and fixed. Furthermore, some of the aggregate data come from sources other than statistical agencies and, therefore, their accuracy cannot be verified. Second, our scenario analysis relies on many assumptions, some of which may not be realistic. For instance, in the BAU scenario, we have taken into account objectives laid out in the five-year development plans and the 20-year vision. However, the record of the government for achieving those targets, especially in most recent years, is not promising. For instance, the projected annual economic growth rate in the fourth and the fifth five-year plans are about 8 percent, but the actual growth rate has been between 1 and 2 percent in those periods. Moreover, our assumptions for efficiency scenario, particularly in the industry sector, rely partly on auditing reports by different public organizations at different times. But the quality of those reports is hard to verify. Third, in our scenario analysis, we have assumed that the energy price reform will be implemented so the energy prices will reflect production costs. Although the energy price reform has already started in Iran, its effect on energy consumption is not certain yet as it is not accompanied by other structural reforms necessary to support the price reform. Nevertheless, we assume that energy subsidies will eventually be removed bringing energy prices closer to border prices, as government cannot continue with its generous energy subsidy programs due to its budgetary constraints in the long run. Finally, our long run scenario analysis abstracts from the political changes in the region and the country, which might not be realistic in the long run.

Acknowledgment: The paper has benefited from contributions by Dieter Seifried, Esfandiar Jahangard, Qumars Heidari, Mohsen Massarat, and Nikolaus Supersberger, for which we are thankful. The authors also thank participants at the IAEE conference in Calgary in October 2010, the IIES seminar in Tehran in Nov. 2010, and the Wuppertal Institute for Climate, Environment, and Energy workshop in May 2010 for their comments. We also thank Joanne Illingworth for providing editorial help. All possible errors are ours. 


\section{References}

Adams, F. G. And Y. Shachmurove (2007), Projections of Chinese Energy Demands in 2020, Penn Institute for Economic Research Working Paper 07-012.

Ahmdian, M., Mona Chitnis, and Lester C. Hunt (2007), Gasoline Demand, Pricing Policy and Social Welfare in the Islamic Republic of Iran, OPEC Review, June.

Aydinalp, M. V. I. Ugursal, and A. S. Fung (2001), "Modelling of Residential Energy Consumption at the National Level," IEMS and ICC\&IE 2001 Joint Meeting, Florida, March.

Bentzen J. and Engsted T. (2001) "A revival of the Autoregressive Distributed Lag Model in Estimating Energy Demand Relationship", Energy 26, 45-55.

Bhattacharyya S., and G. R. Timilsina (2010), A Review of Energy System Models, International Journal of Energy Sector Management, 4, 4, 494-518.

Central Bank of Iran, Economic Indicators, 2005-2009.

City of Tehran, Tehran Transportation and Traffic Studies, 2005-2009.

Crompton, P., and Y. Wu (2005), Energy Consumption in China: Past Trends and Future Directions, Energy Economics, 27, 1, 195-208.

Davoudpour, H., and M. S. Ahadi (2006), The Potential for Greenhouse Gases Mitigation in Household Sector of Iran: Cases of Price Reform/Efficiency Improvement and Scenario for 2000-2010, Energy Policy, 34, 40-49.

DLR (2005): Concentrating Solar Power for the Mediterranean Region. Deutsches Zentrum für Luft- und Raumfahrt e.V. (DLR), Stuttgart.

Economist Intelligence Unit (2006), Iran: Energy and Electricity Profile.

Farahbakhsh, H., V. I. Ugursal, and A. S. Fung (1998), A residential end-use energy consumption model for Canada, International Journal of Energy Research, 22, 13, 1133-1143.

Farzanegan M. R. and G. Markwardt (2009), The Effects of Oil Price Shocks on the Iranian Economy, Energy Economics, 31, 134-151.

Fettini, Habib (2003), Iran: Medium Term Framework for Transition, Converting Oil Wealth to Development, A Country Economic Memorandum, World Bank, Social and Economic Development Group, Middle East and North Africa Region, Report No. 25848-IRN, April 30, 2003. 
Filippini M. And L. C. Hunt (2011), Energy Demand and Energy Efficiency in the OECD Countries: A Stochastic Demand Frontier Approach, the Energy Journal, 32, 2, 59-80.

Fung, A. S., B. Guler, M. Aydinalp, and V. I. Ugursal (2000), "Development of Canadian Residential Energy End-use and Emission Model (CREEEM), CREEDAC report No. 2000-8-3, September.

Graus Wina, and Mirjam Harmelink (2006), Global Low Energy Demand Scenarios 2003-2050, Ecofys BV, Project No. ECS05100, Deutsches Zentrium Fur Luft-und Raumfahrt (DLR), August.

Griffith, B., N. Long, P. Torcellini, and R. Judkoff , D. Crawley and J. Ryan (2007), Assessment of the Technical Potential for Achieving Net Zero-Energy Buildings in the Commercial Sector, National Renewable Energy Laboratory, Technical Report NREL/TP-550-41957.

Haas R. and L. Schipper (1998), "Residential Energy Demand in OECD Countries and the Role of Irreversible Efficiency Improvements: Evidence from the period 1970-1993”. Energy Economics, 20.

Huang Y. J. And J. Broderick (2000), A Bottom-up Engineering Estimate of the Aggregate Heating and Cooling Loads of the Entire U.S. Building Stock, Proceedings of the 2000 ACEEE Summer Study on Energy Efficiency in Building, August 2000, Pacific Grove, CA.

IFCO, Optimizing Energy Consumption in Industry Sector in the Next 20 Years, Iranian Fuel Conservation Organization, Tehran, 2007.

International Energy Agency (IEA), World Energy Outlook (2004, 2008), OECD.

Jiang, Kejun, and Xiulian Hu (2005), Energy Demand and Emissions in 2030 in China, Scenarios and Policy Options, Environmental Economics and Policy Studies, 7, 233-250.

Kohler, N., Quante, K., Wagner, A. and Moosmann, C. (2004), Low emission buildings (LEB): Final Report, Institut fur Industrielle Bauproduktion and Fachbereich Technischer Ausbau, University of Karlsruhe, Karlsruhe.

Koopmans C. C., and D. W. te Velde (2001), Bridging the Efficiency Gap: Using Bottom-up Information in a Top-down Energy Demand Model, Energy Economics, 23, 57-75.

Larsen, B. M. and R. Nesbakken (2004), Household Electricity End-use Consumption: Results from Econometric and Engineering Models, Energy Economics, 26, 179-200.

Lechtenböhmer, S., Schüring, A. (2011): The potential for large scale savings from insulating residential buildings in the EU, Energy Efficiency, Volume 4, Issue 2 (2011), Page 257-270 (DOI:

10.1007/s12053-010-9090-6) 
Lechtenböhmer, S., Samadi, S., Schneider, C. (2011): The Potential Role of Energy Efficiency in the Transition to a Low Carbon Society - A Critical Scenario Review. ECEEE summer study 2011 proceedings, forthcoming

Medlock, K. and Soligo, R. 2001. Economic development and end-use energy demand, Energy Journal 22(2), 77-105.

Ministry of Energy, Iranian Energy Balance, 2005 -2007.

Ministry of Road and Transportation (2005), Comprehensive Transportation Studies of Iran, Tehran.

Ministry of Road and Transportation, Road Transportation Annual Report, different years.Palmer J., Boardman B., Bottrill C., Darby S., Hinnells M., Killip G., Layberry R., Lovell H. (2006) Reducing the environmental impact of housing. Final Report. Consultancy study in support of the Royal Commission on Environmental Pollution's 26th Report on the Urban Environment.

Murakami, S, M.D. Levine, H. Yoshino, T. Inoue, T. Ikaga,Y. Shimoda, S. Miura, T. Sera, M. N.ishio, Y. Sakamoto, and W. Fujisaki (2009), Overview of energy consumption and GHG mitigation technologies in the building sector of Japan, Energy Efficiency 2, 179-194.

Pesaran, M.H., R. P. Smith, and T. Akiama (1998), Energy Demand in Asian Developing Economies, World Bank Studies, Oxford University Press.

Rana, Ashish (2003), Evaluation of a Renewable Energy Scenario in India for Economic and CO2 Migrations Effects, Th applied Regional Science Conference (ARSC), RURDS, Vol 15, No. 1, March.

Sadeghi, M. and H. M. Hosseini (2008), Integrated Energy Planning For Transport Sector - A Case Study of Iran with Techno-economic Approach, Energy Policy, 36, 5, 1726-35.

Statistics Center of Iran (2004), The Large Manufacturing Industries Survey, various years.

Swan L. G. And V. I. Ugursal (2009), Modeling of End-use Energy Consumption in the Residential Sector: A Review of Modeling Techniques, Renewable and Sustainable Energy Reviews 13, 8 , 1819-1835.

TAVANIR, Energy Savings in Audited Industries, Tehran Regional Electricity Company (TREC), various reports, 1999-2005.

TAVANIR, Reports by “The Consumption Management Office”, Production, Transmission, and Distribution Company, TAVANIR, 1996, 2001. 
TREC, A study of household's electricity consumption pattern and their satisfaction in Tehran, Tehran Regional Electricity Company, different years.

Urban, F., R. M. J. Benders, and H. C. Moll (2007), Modeling Energy Systems for Developing Countries, Energy Policy, 35, 6, 3473-82.

Energy Information Administration, International Energy Statistics ( http://www.eia.gov), U.S., 2011.

Van Benthem, A., and M. Romani (2009), Fueling Growth; What Drives Energy Demand in Developing Countries? the Energy Journal, 30, 3, 93-114.

World Energy Outlook (2008), International Energy Agency, OECD. 
${ }^{1}$ AAAS Atlas of Population and Environment lists Tehran among the most polluted cities in the world (http://atlas.aaas.org)

${ }^{2}$ For a comparison between econometric models (conditional demand analysis) and end-use models see Larsen and Nesbakken (2004) and for a survey on modeling techniques see Swan and Ugursal (2009), and Bhattacharyya and Timilsina (2010).

${ }^{3}$ Subsidies include direct payments by government and indirect or hidden subsidies calculated as the difference between the domestic and border prices.

${ }^{4}$ Due to space limit, we do not present all our calculations. The detailed information will be available from the authors upon request.

${ }^{5}$ Fluorescent lamps are old long or round fluorescent lamps, and Low Consumption Lamps are compact fluorescent lamps (CFLs).

${ }^{6}$ To estimate the cooler penetration rate, the information on electricity use in the "very hot" and "hot" regions is used. In the very hot and humid regions, like southern and some northern areas, people use an air conditioner in hot months. We first estimate the number of coolers used by households using the household electricity consumption information for those regions in hot and cold months (three months) and the average electricity consumption by type of coolers used in Iran. In total, there are about 16 million households using electricity in Iran, from which about 3.2 million households live in the hot areas (70 percent in very hot areas and 30 percent in hot areas.) The water system and gas system cooler penetration rates are calculated based on the weighted average of the cooler stock in Iran.

${ }^{7}$ There is a discrepancy between the data published by the Iranian Statistics Center (ISC) and the Ministry of Energy in the Energy Balance (EB) on the energy use by the manufacturing industries. This is mainly due to the difference in the samples used by these two agencies. Here, we have taken the total energy use from EB and distributed its difference with ISC among the industries using their shares from ISC.

${ }^{8}$ Gasoline price is not a significant factor as it has been kept very low for a long period.

${ }^{9}$ One of the main items in the government economic reform plan, which began in 2010, is to remove energy subsidies in five years. Specifically, the gasoline price would increase to border price and utility bills would reflect their production costs. .

${ }^{10}$ There are other pollutants such as $\mathrm{SO} 2, \mathrm{NO}_{x}$, dust, $\mathrm{CO}$, and heavy metals like lead, which are generated during the combustion of oil and gas in the industry and the transport sectors and constitute a massive risk to humans and the environment. We have not included these external costs imposed on health and environment in our analysis. 
Figure 1- Total Final Energy Demand by Sectors, BAU Scenario (2005-2030)

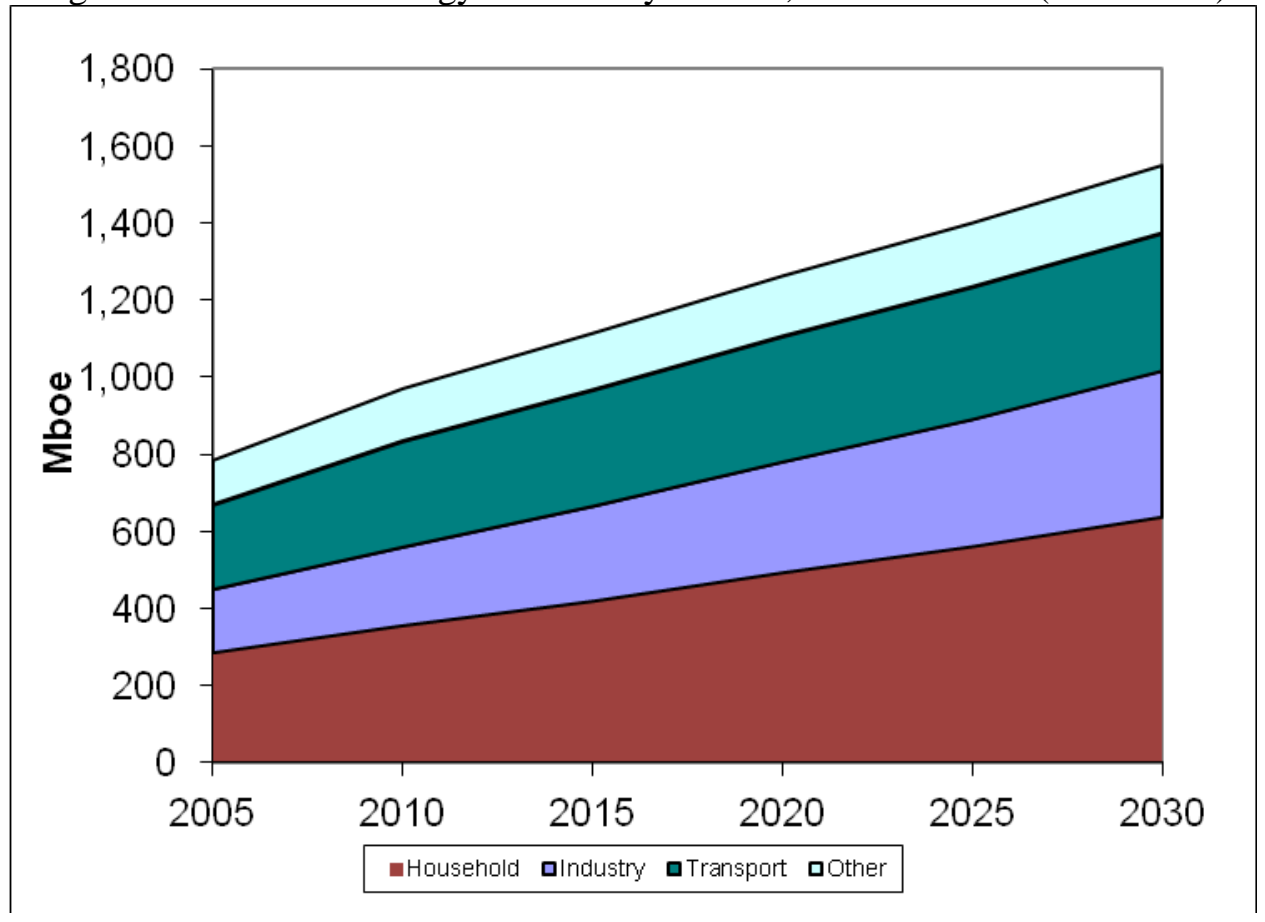

Figure 2 - Total Energy Demand by Energy Type, BAU Scenario (2005-2030)

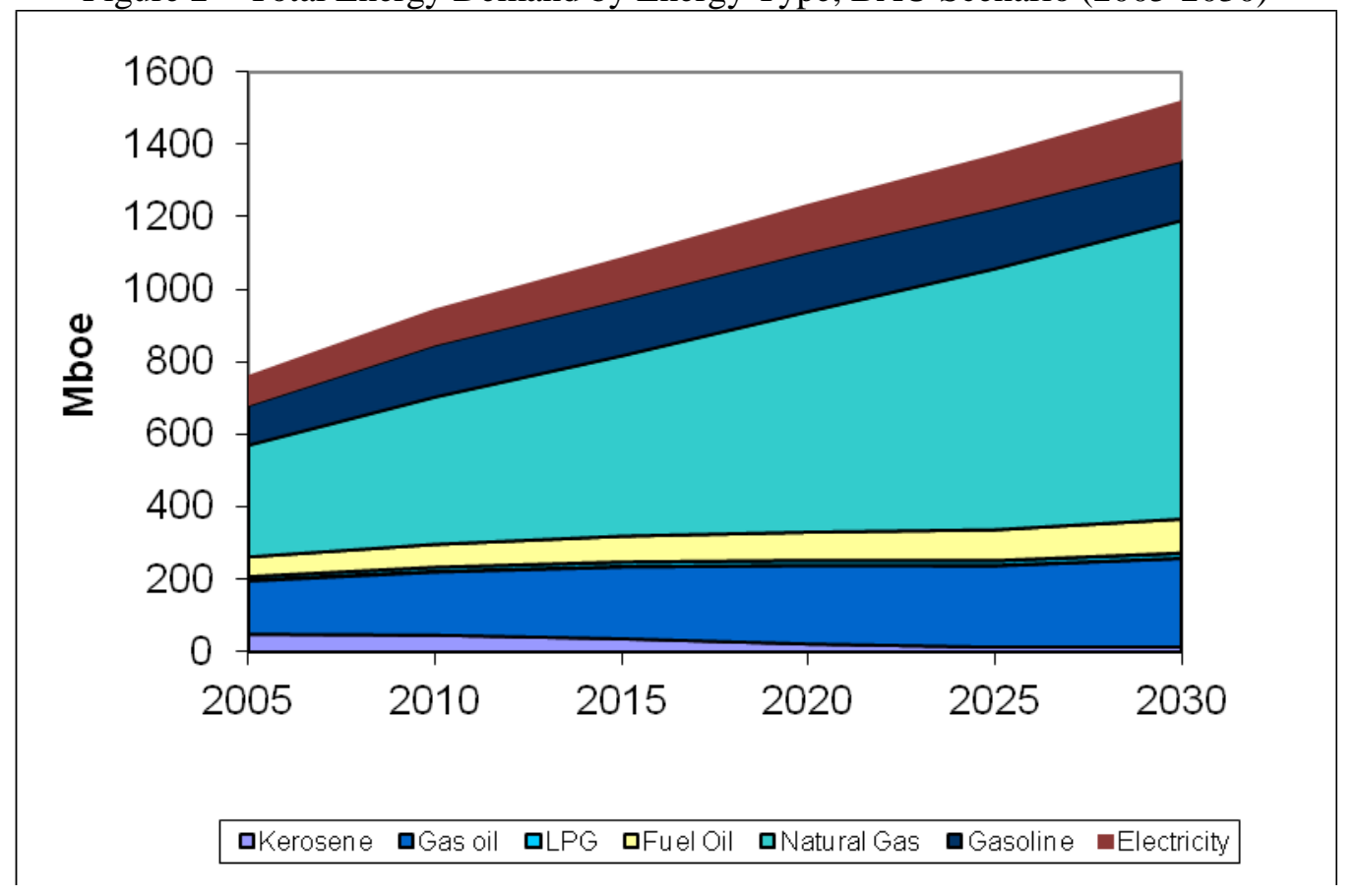


Figure 3 - The Energy Demand Scenario Results (2005-2030), Mboe

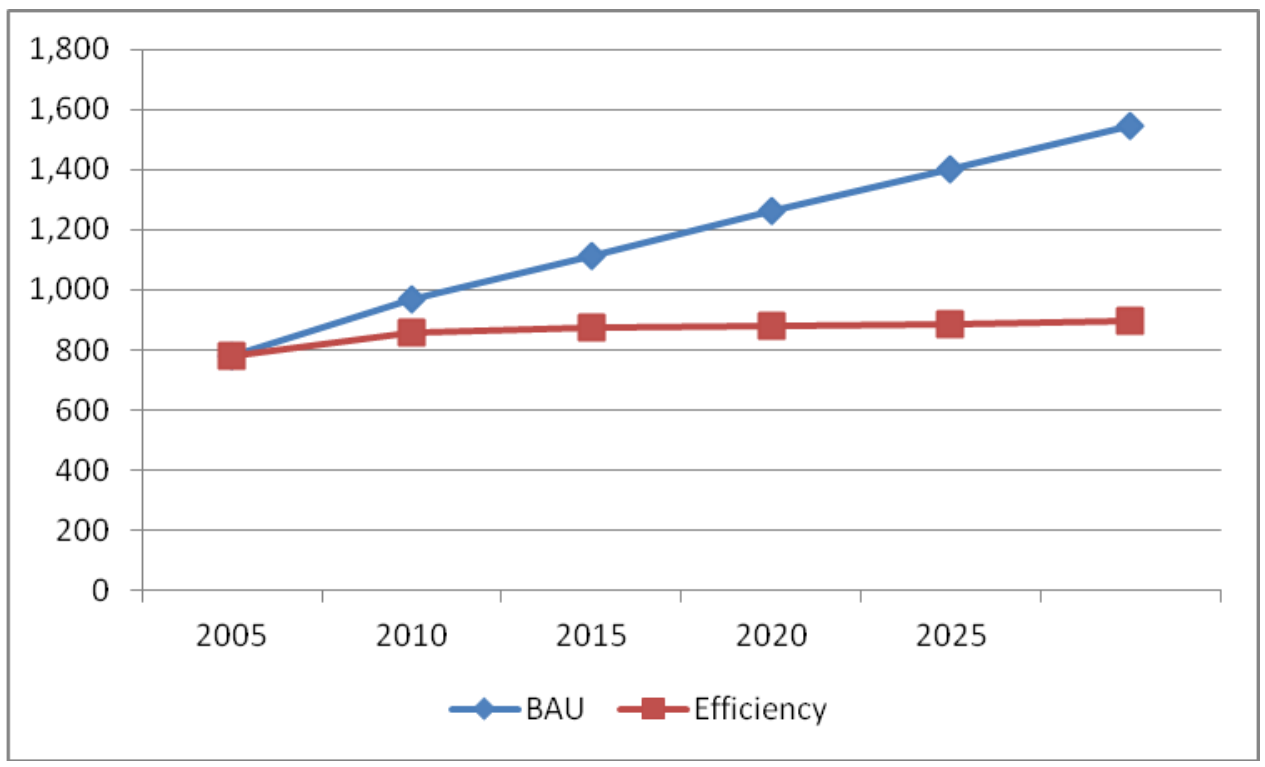



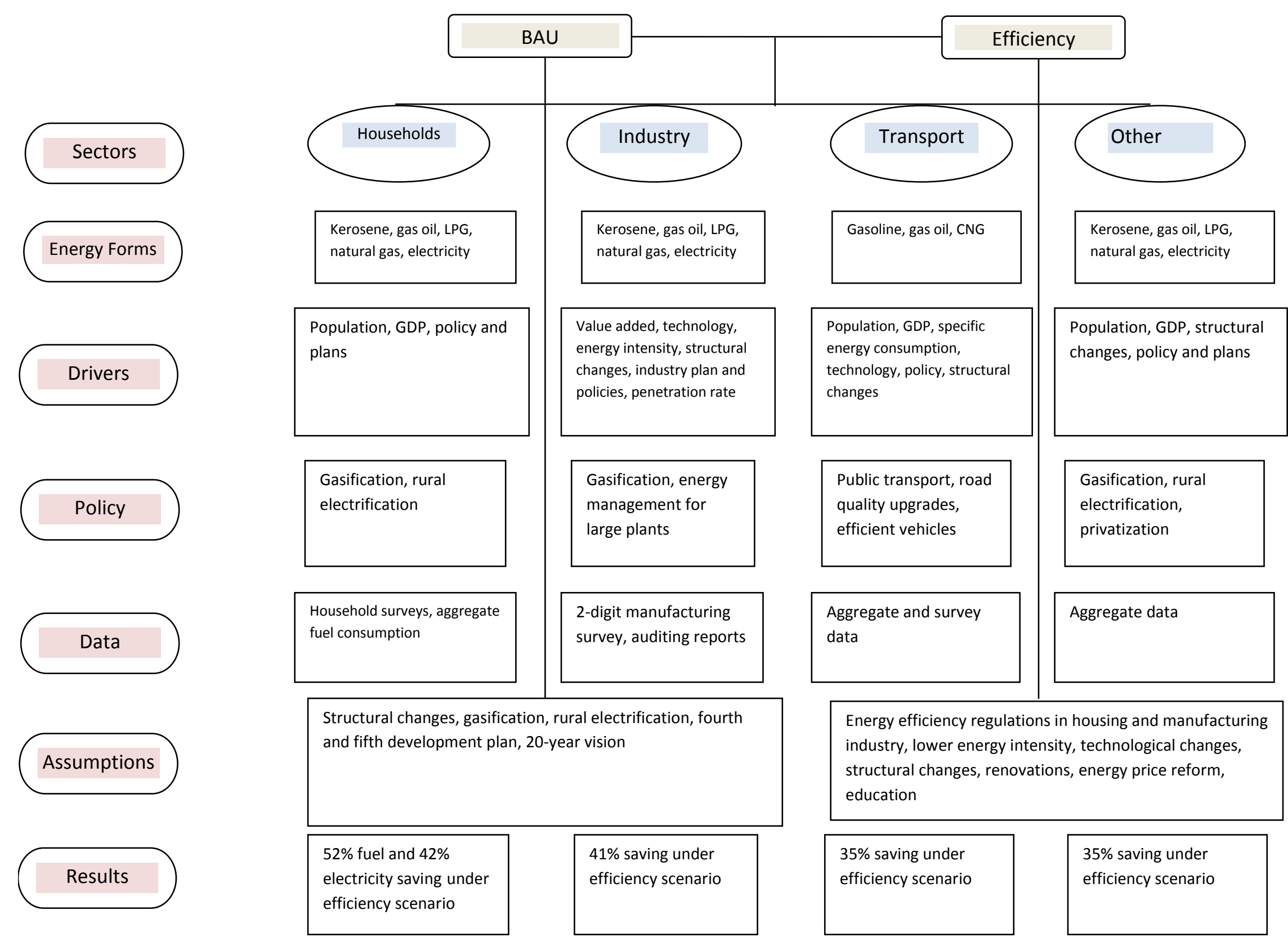